\title{
The Problems and Reform of Art and Design Education in Colleges and Universities in China
}

\author{
Xiangdong Dou \\ College of Fine Arts, Shaanxi Normal University, Xi'an, China \\ Email: guicaitang@163.com
}

Received 12 October 2015; accepted 23 November 2015; published 26 November 2015

Copyright @ 2015 by author and Scientific Research Publishing Inc.

This work is licensed under the Creative Commons Attribution International License (CC BY).

http://creativecommons.org/licenses/by/4.0/

(c) (i) Open Access

\begin{abstract}
The modern art education was originated from Germany Faculty of Bauhaus, dating back more than 100 years, while our art and design education is still at primary stage, only with a history of 50 years. But we are enjoying a good development trend in art and design education and it develops fast. In such a fast developmental course, it is inevitable to produce various problems. This paper mainly analyzed the problems in art and design education in our colleges and universities and put forward some feasible reform programs.
\end{abstract}

\section{Keywords}

\section{Art and Design, Art and Design Education, Problems, Countermeasures}

\section{Introduction}

Art and design education has a long history. Since the establishment of Germany Faculty of Bauhaus in the last century, Eaton has opened many professional courses. His education methods have a great significance to art and design education. The art and design education in our domestic colleges and universities is established on this basis. Modern art and design education is the fruits of many people's efforts. Modern education attaches importance to giving full play of students' personal ability, and further improving the teaching system. But there are still many problems in this process, and it is worth the attention of this cycle.

\section{The Concept of Art and Design Education}

Before we understand "art and design education”, first we need to clear a concept: what is "art and design" on earth? In fact, art and design refers to the design process of daily things by art methods before processing, in- 
volving people's life equipment, applied tools, clothes and jewelry and so on. In other words, the art and design is actually earlier than the creation activity. It is a kind of subjective plan, always adhering to "the principle of creating things according to the law of beauty". Art and design is closely related to people's life, involving food, clothing, traveling and etc. (Chen, 2012).

Art and design education is also known as "design education". The scope of design education is very extensive, including professional education for the cultivation of professionals, basic knowledge for the improvement of quality, and general education for the cultivation of basic skills and aesthetic ability. First of all, art and design education is based on the relevant theoretic and basic knowledge. It stresses on the cultivation of design ability and concept, focuses on the training of students' design methods and skills in daily study, and thus improving students' innovation ability and future development potential. In this way students can meet the needs for the development of art and design, creation, teaching and other related fields. Secondly, the art and design education is not specifically for a certain industry, so learning of skills and related experience shall not be treated as main route in the teaching, and the vocational education shall not be considered as the only goal of the course. Colleges and universities should develop their courses based on personality education, develop students' sense and reason, and place the artistic conception, connotation and culture as the key points in the teaching of modern art and design activities, improve students' professional quality and aesthetic level. This is the goal of the art and design education that colleges and universities should realize.

\section{The Existing Problems of Art and Design Education in China}

\subsection{Treating Art and Design as a Branch of Fine Arts}

There is no uniform standard for modern art education, which is the difference from other disciplines. This mainly depends on a different market conditions for design. Art and design involves a wide range of fields, such as product design, industrial design, tool design, logo design, advertising design, fashion design, layout design, architectural environment design, and so on. This discipline often has strong application hue and has relative high technical requirements (Jiang, 2011). At present, this circle often treats technical design as a typical comprehensive discipline. Its scope of knowledge is not just confined to a certain field, but it has a close relationship with science and technology, engineering technology and etc, which is very different from the modality of fine arts. Due to the rapid development of information technology, it gradually produces certain distinction between art and design and painting. Art and design uses painting as a means or medium, but its essence is different from that of painting. As a typical art style, fine arts has obvious hue of human nature, for it reflects and expresses the emotions of artists. But design is different. Its service object is the mass and the society. So the difference between them is still very obvious. Therefore, we can not simply consider art and design as art education. But our current domestic art and design education is a simple art education. It is only the replica of traditional arts and crafts education, and does not realize the value of modern art and design education, for it does not accord with the practical needs of art and design education. The idea that takes the educational method of fine arts in place of the education of design is the crux of domestic art and design education.

\subsection{The Unreasonable Structure of Teacher Team}

At present, there are mainly two types of teachers for art and design in our colleges and universities. One is the teachers graduated from the fine arts colleges and universities. Most of their education background is pure fine arts, such as Chinese painting, oil painting, sculpture and so on. They were assigned to different colleges and universities to work on art and design education after graduation. Some of them give professional training in the art and design education (Kang, 2013). Some of them need to learn relevant knowledge by themselves. The other is the teachers graduated from the industrial arts colleges and universities. Such teachers are more in line with the requirements of art and design compared with teachers majoring in fine arts, because they have good professional knowledge of art and design and practical ability. But this kind of talent is relatively few. Gradually it has become a common view in domestic art and design colleges and universities, although domestic art education has some excellent teachers, such as Overseas Returnee Lei Guiyuan and Zheng Ke of last century, who have strong art and design professional ability. In last century, China has cultivated a number of professionals by our own strength. These professionals later became the backbone of domestic art and design education. In the 1980s, the state had sent a group of students to study abroad, of which some students were special to learn professional 
art and design. These students have introduced advanced foreign practice methods, practical information and teaching methods, and have provided certain experience for domestic education. Based on the experience, we reformed our previous curriculum setting and shortened the gap between domestic art and design level and foreign art and design level. It provides a guarantee for the progress of domestic design education. However, the art and design education system wholly is not scientific. Many domestic art institutions have no professional teachers for teaching, among which excellent teacher is fewer. Most of the teachers teach students in a perfunctory manner, which is certainly related to the unreasonable teacher formation in colleges and universities, but mainly depends on the limitation of teachers' professional level. Our art and design education has no characteristics, profundity, accuracy and extention, for it has been accustomed to stay on the surface. This leads to students' lack of confidence, and they do not dare to participate in the important design task. It is difficult for them to seize a favorable position in the fierce social competition. This increases the difficulty for students to fit into society. And there are still some drawbacks in their design thinking and creativity, which is the most important challenge in the domestic design education.

\subsection{The Unscientific Education Management Mode}

Under the guidance of economic interests, our universities and colleges are experiencing the "large and complete" departments and sectors construction. We started to set a variety of majors since the end of last century. Under the guidance of the concept that we can start if we have conditions and we can create conditions and then start if we have no conditions, many domestic colleges and universities started to set up art and design major. This kind of situation spreads in a short time with obvious expansion and strong willfulness. They have no specific system or regulations to control subject setting, professional conditions, teaching target, cultivation program and direction and etc. The start of domestic art and design was such a bit hasty. Many colleges and universities even set up curriculum and carry out teaching according to teachers' conditions rather than strictly according to the teaching plan. They even can reduce or add class hours at their will, which makes teaching lack of scientificity and systematicness. In addition, the unreasonable setting of art and design education in our colleges and universities results in waste of talent resources. For example, many local colleges and universities often use a large number of "malarkey" and "polite formula" due to restrictions on outlay and teacher resources when they determine their teaching objective of art, and they did not really consider their school characteristics and style during the process of objective design, so teachers do not know which aspect they should emphasize in their teaching activities and so they hardly find the difference of graduates in ability level and speciality (Li, 2011).

\section{Reform and Innovation of Domestic Art Education}

\subsection{Improve the Level of Theory Accomplishment, Change Education Concepts}

What urgently need to be solved by domestic advanced art education is not to set up different specialties according to artistic phenomenon. Facing all kinds of phenomena, we need to use rigorous attitude in academic research to build scientific and systematic basic disciplines containing humanistic spirit to improve students' overall literacy level and let them find the value and significance of humanities. No matter art theory or natural science and social science, all of them are treasures in human history. Theoretical study can help designers to improve their literacy. If students cannot form profound cognition and feelings in practice, they are very short of theoretical study.

With constant deepening of domestic education reform and rapid market operation, domestic colleges and universities begin to increase the number of student enrollment of art and design education specialty. But the educational condition of most colleges and universities still rests on the level of the last century, without good software condition: the team structure of professional teachers is very unreasonable. Existing for more than 50 years, domestic art and design education has relatively solid foundation through unceasing efforts of many people and has provided a lot of outstanding professionals for domestic economic construction. However, having the whole world in view, there is no small gap between domestic art and design education specialty and other countries'. The basic condition to set up an art and design colleges and universities in a leading position is the level and quality of teachers.

Looking from the perspective of art and design education, although people emphasize the importance of creative education long before, most schools cannot realize this point and they still follow the old method. When 
some schools do course arrangement, courses of skills training can account for more than eighty percents but they don't arrange disciplines of basic literacy, which make students have good painting ability but lack of humanistic feelings. They can only imitate without innovation. The primary cause is that the art and design education in schools still uses traditional art education mode, without considering actual requirements of design specialty. For students in art and design, creativity is of vital importance. Theory is the root of creativity and its richness directly determines whether designers have ideas. It needs artists to spend a lifetime in practicing and studying constantly. These ideas are the most precious soul in art and design field and educators must not neglect its value. Only through correct understanding of art and design can colleges and universities cultivate excellent art and design talents that meet the requirement of social development (Liu, 2014).

\subsection{Reform Course Setting}

How should we help students to establish good creative ability? It can be realized gradually by professional schools to use scientific course setting and teaching contents in the process of training. In course setting, except for setting related courses in accordance with national requirements, colleges and universities should classify the specialized courses. Specialized courses mainly include the following parts: basic modeling course, design basis, professional design and theory on design. Basic modeling course is composed of several aspects: sketch, color, modeling and craft. The significance of this kind of course is to help students to improve the ability of observation and then acquire better artistic performance ability. Some colleges attach importance to the teaching of structure sketching. In practice, the requirements of it and painting specialty are the same: the sketch of painting specialty also pays attention to structure. But it needs to be noticed that the sketch in design specialty also covers utensils and tools, etc. This kind of course of some design colleges and universities in western countries covers little class hours. Some schools even just don't set up this kind of course. The significance of basic training of modeling is to improve students' expressive ability as well as aesthetic judgment ability and creativity. Under normal conditions, people with modeling ability can better express their aesthetic idea.

Design basis also covers many contents, such as traditional pattern, three components, font, design representation and model making, etc. The significance of setting such course is that: first of all, it can help students to master design skills; secondly, it helps students to have more profound understanding of design fields. The related fields mentioned here mainly include material, craft, creation method, space, form and color, etc. Knowledge of these aspects will lay solid foundation for design. Some colleges and universities place the contents of three components in the key position of basic course of design. They think students can learn design well if they master three components. It makes students put more emphasis on form and neglect the true meaning of practice. When teaching basic course of design, computer has become the most important tool, so the design method has changed obviously. But teachers still should attach importance to manual training.

\subsection{Improve the Form of Education Management}

Domestic specialty of art and design education has a relatively short history and most of them are established in the 1980s. The specialty in domestic colleges and universities is young, without considering its own situation. Most schools adopt unified mode of "teaching of architecture design", lack of characteristics. With rapid progress of market economy, the setting of this specialty in our country obvious cannot meet domestic requirements, which lead to the fact that talents cultivated by schools become unqualified after stepping into society and the waste of talents appears. Domestic colleges and universities attach importance to theory teaching while neglect the value of practice. Domestic art and design education often adopt the method of arts and crafts education, pay attention to traditional theoretical study and neglect the characteristic of learning. But problems in teaching just need to be found in practice. So for the practical teaching of art and design, it has very significant value and meaning. Without specialized practice opportunities and professionals as teachers, students' design almost relies on imagination. In this way, students cannot know the real needs of society and get effective connect, which make theory cannot be applied in practice (Tu, 2014).

\section{Conclusion}

The era that belongs to design has quietly come. The art and design education in colleges and universities has ushered in the key stage of its own development history. It has very important significance and value to reform 
the art and design education in colleges and universities, improve the overall educational level of domestic art and design talents and promote its long-term and healthy development in our country. The origin of modern art education is Staatliches Bauhaus in Germany, which has more than hundred years of history before present. With a history of about fifty years, domestic art and design education is still in its infancy. Now the education method pays attention to fully exerting students' personal abilities and perfecting the teaching system. But during this process, many problems still exist for us to pay close attention to. Domestic art and design education has good and rapid development momentum. In such a rapid process of development, it is inevitable to appear different kinds of problems. This article mainly analyzes the existing problems in art and design education in domestic colleges and universities as well as the feasible reform measures. We should create a good learning environment for students, introduce advanced educational ideas and concepts and correctly know the existing problems and challenges in the process of art and design education. Today, with rapid economic development and industrialization of education, domestic colleges and universities make great efforts to establish higher education of high quality all the time. For the overall level of higher education, it has fundamental and important effect for art and design education to truly find a method that meets the requirements of its own and the society as well.

\section{References}

Chen, Q., \& Zhang, G. X. (2012). Discussion on the Reform of Art and Design Education in Local Colleges and Universities. Journal of Hunan University of Art and Science (Social Science Edition), No. 04, 258.

Jiang, S. M. (2011). Thinking on the Current Situation and Reform of Art and Design Education in Domestic Contemporary Colleges and Universities. Bilingual Learning, No. 11, 369.

Kang, J. (2013). Discussion on Contemporary Art and Design Education from the Evolution of Related Concepts. Sci-Tech Information Development \& Economy, No. 10, 251.

Li, J. (2011). Creating Platform for Art and Design Education and Building Studio Teaching Group Mode-Analysis on Studio Teaching Group Mode under Credit System in Art Institute of Higher Learning. Art Education, No. 08, 963.

Liu, C. (2014). Current Situation of Art and Design Education and Market Requirements. Pioneering with Science \& Technology Monthly, No. 09, 85.

Tu, S. G. (2014). Problems and Countermeasures of Current Domestic Artistic Design in Postgraduate Education. Journal of Nanjing Art Institute (Fine Arts \& Design), No. 03, 159. 